\title{
Towards a Right to Resist Gross Undemocratic Practices in Africa
}

\author{
Pacifique Manirakiza* \\ University of Ottawa \\ Pacifique.Manirakiza@uottawa.ca
}

\begin{abstract}
The adoption of the African Charter on Democracy, Elections and Governance (ACDEG) has been a milestone for the transformation of Africa's political landscape. This instrument seeks to expand on the ideals of liberal democracy enshrined in the Constitutive Act of the African Union and other African fundamental instruments. The ACDEG seems to pave the way for the right to democracy for Africans, which entails, inter alia, political sovereignty of African citizens. The latter have clearly and vigorously exercised their sovereignty through elections when given such an opportunity. However, in some instances, African citizens resorted to popular uprisings in cases of gross violations of their democracy-related rights. With reference to the recent popular uprisings and coups (or attempted coups) in Africa, this article enquires, from a human rights perspective, whether ACDEG or other instruments, enshrine a right to resist gross undemocratic practices underpinning the right to democracy.
\end{abstract}

\section{Keywords}

Resistance theory, self-determination, popular participation, undemocratic practices, Africans' agency, moderate resistance, radical resistance, African Charter on Democracy Elections and Governance

\section{INTRODUCTION}

The adoption of the African Charter on Democracy, Elections and Governance (ACDEG) and its subsequent entry into force ${ }^{1}$ has been a milestone in the transformation of the African democratic landscape. This instrument basically seeks to expand on the ideals of liberal democracy ${ }^{2}$ enshrined in the

* Professor of law, University of Ottawa. Former commissioner, African Commission on Human and Peoples' Rights.

1 AU doc Assembly/AU/Dec.147 (VIII), adopted by the eighth ordinary session of the Assembly of Heads of State and Government (Assembly) held in Addis Ababa, Ethiopia, 30 January 2007; entered into force 20 February 2012.

2 Schumpeter defines "liberal democracy" as an "institutional arrangement for arriving at political decisions in which individuals acquire the power to decide by means of competitive struggle for the people's vote": JA Schumpeter Capitalism, Socialism and Democracy (1965, Routledge) at 284. The liberal democracy is one of the different forms of democracy listed by Pinkey and the most prevalent as of today: R Pinkney Democracy in the Third World (2nd ed, 2003, Lynne Rienner) at 10-15. 
Constitutive Act of the African Union (AU) and other fundamental AU instruments. ${ }^{3}$ Although the ACDEG does not explicitly provide for the right to democracy as such, it has nevertheless paved the way for the enjoyment of that right, mainly because it contains numerous democracy-related provisions, including those dealing with the supremacy of the constitution, ${ }^{4}$ popular participation ${ }^{5}$ and elections. ${ }^{6}$ Africans' enjoyment of these democracy-related rights will, hopefully, help root a democratic culture for better governance across the continent.

For African citizens, the right to democracy is fundamental. It simultaneously gives them the ability both to enjoy and to exercise their political sovereignty. A major component of the right to democracy is the right for African citizenry to participate freely in political processes aimed at shaping and putting in place political, economic or social institutions. ${ }^{7}$ Not only are citizens contributing to create institutions, they are also required to respect and comply with them. ${ }^{8}$ In theory, these institutions, in particular the government, are chosen and tasked to ensure peoples' betterment, including the promotion and protection of fundamental human rights. In fact, gross and systematic violations of human and peoples' rights represent "a case of falling below minimum standards required for political institutions". ${ }^{9}$ However, in practice, most governments are embroiled in human rights violations despite their clear legal duties to abide by basic human rights instruments as well as their constitutions. ${ }^{10}$ In particular, democratic rights are in jeopardy because of untimely constitutional amendments, made to enable incumbent leaders to stay in power. ${ }^{11}$ Also, sham elections remain frequent, not to mention

3 Constitutive Act of the African Union, AHG/Dec.143 (XXXVI), adopted by the 36th ordinary session of the Assembly, Lomé, Togo, 11 July 2000, arts 3(g)(h) and 4(k)-(p); African Charter on Human and Peoples' Rights, OAU doc CAB/LEG/67/3 rev 5, 21 ILM 58 (1982), adopted by the 18th Assembly, held in Nairobi, Kenya, 27 June 1981, entered into force 21 October 1986, arts 13 and 20.

4 ACDEG, arts 2(2) and 10(1).

5 Id, arts 44(1), 2(10) and 3(7).

6 Id, arts $17-22$.

7 Ibid.

8 CJ Finlay Terrorism and the Right to Resist: A Theory of Just Revolutionary War (2015, Cambridge University Press) at 45.

9 TM Scanlon "Human rights as a neutral concern" in TM Scanlon (ed) The Difficulty of Tolerance: Essays in Political Philosophy (2003, Cambridge University Press) 113 at 113.

10 Final Communiqué of the 60th Ordinary Session of the African Commission on Human and Peoples' Rights (Niamey, Republic of Niger 8-22 May 2017), para 16.

11 This has been the case in Rwanda and Burundi. The former amended its constitution in order to allow a third term for President Kagame. The latter also went through a constitutional amendment process that culminated in a popular referendum on 17 May 2018. Contrary to his Rwandan counterpart, the incumbent Burundian president, $\mathrm{Mr}$ Nkurunziza, has indicated that he will not run for the office under the terms of the new constitution, despite rumours and speculation from the opposition that the entire process was set in motion for him to rerun for the presidency in 2020. On Burundi, see $S$ Vandeginste "Burundi's constitutional amendment: What do we know so far?" (Analysis and Policy Brief no 24, Institute of Development Policy, University of Antwerp, November 
massive or serious violations of fundamental human and peoples' rights, ${ }^{12}$ especially the right to participate in public affairs and to freedom of expression, which are intrinsically linked to the right to democracy. Both the clinging onto power and massive or serious violations of basic human rights can be characterized as gross undemocratic practices. There is no official definition so far for the concept of gross undemocratic practices. In this article, the concept alludes to any conduct by an individual, a group of individuals, a non-state actor or a government seriously inimical to the enjoyment and the exercise of the right to democracy. Concretely, gross undemocratic practices amount to serious acts or omissions threatening to breach or breaching the constitutional order, or causing massive or serious violations of democracy-related human rights, the spill-over effects of which may be transnational and likely to cause regional or sub-regional instability or insecurity. ${ }^{13}$ The ACDEG and other AU legal instruments and policy documents tackle the issue of serious undemocratic practices. For instance, the former prohibits unconstitutional changes of government, which are all illegal means of accessing or staying in power, ${ }^{14}$ jeopardizing peoples' aspirations to the rule of law and good democratic governance. However, as highlighted above, the basic democracyprone AU instruments fall short on whether citizens are entitled to oppose undemocratic practices outside electoral processes. While holding elections and respecting the rule of law are undoubtedly an important recipe, they will not cure all democratic governance issues. The recipe is effective in normal circumstances, when all state institutions are functioning properly. In the opposite scenario, citizens are left with few options. In some countries, African citizens have taken to the streets or the military has intervened to

contd

2017); also S Vandeginste "Burundi's constitutional referendum: Consolidating the fait accompli in the run-up to the 2020 elections" (23 January 2018) Constitutionnet, available at: <http://www.constitutionnet.org/news/burundis-constitutional-referendumconsolidating-fait-accompli-run-2020-elections> (last accessed 11 December 2018).

12 See for instance the 43rd Activity Report of the African Commission on Human and Peoples' Rights Submitted in Accordance with Article 54 of the African Charter on Human and Peoples' Rights, para 36; the 42nd Activity Report of the African Commission on Human and Peoples' Rights, Submitted in Accordance with Article 54 of the African Charter on Human and Peoples' Rights, para 43.

13 The Assembly has highlighted the link between political instability, democracy deficit and unconstitutional regime change; see Decision on the Resurgence of the Scourge of Coups d'État in Africa, doc Assembly/AU/Dec.220(XII), para 1. For the Assembly, an unconstitutional change of government “... undermines the progress achieved in the ongoing democratization processes in the Continent and constitutes a threat to peace and security in Africa"; see Decision on the Prevention of Unconstitutional Changes of Government and Strengthening the Capacity of the African Union to Manage Such Situations, doc Assembly/AU/4(XVI): Assembly/AU/Dec.269(XIV) rev 1, para 3.

14 The suggested definition is based on the definition of unconstitutional changes of government; see ACDEG, art 23 and the Lomé Declaration of July 2000 on the Framework for an OAU Response to Unconstitutional Changes of Government, AHG/Decl.5 (XXXVI). 
protest against unaddressed serious undemocratic practices. This is best depicted in recent popular uprisings and coups d'état (or attempted coups) in Africa. ${ }^{15}$ Such popular uprisings and coups are purportedly perpetrated in the name of constitutional order and the right to democracy, especially the right to voice citizens' concerns as to how a particular country is or should be run.

This article interrogates the legality of these actions and, most importantly, inquires, from a human rights approach, whether there exists a right to resist gross undemocratic practices underpinning the right to democracy. The first part analyses the legal and philosophical underpinnings of the right to resist gross undemocratic practices. After an exploration of how Enlightenment philosophers and political scientists and those inspired by them have theorized the right to resist, the article explores the legal foundations of this right in both international and African human rights law. In particular, it delves into the ACDEG in order to ascertain whether it enshrines a right to resist gross undemocratic practices. The next part tackles the issue of how to raise African citizens' agency to resist gross undemocratic practices. It analyses why and how African citizenry should be empowered, and the test to be fulfilled in order to invoke and exercise the right to resist legitimately. Empowering African citizens through the right to resist is crucial, since it enables African citizens to take care of the protection of their own rights, especially when state institutions are reluctant, unable or unwilling to take on such a task.

\section{PHILOSOPHICAL AND LEGAL UNDERPINNINGS OF THE RIGHT TO RESIST DEMOCRATIC HUMAN RIGHTS VIOLATIONS}

The status of the right to resist the violations of democracy-related human rights cannot be fully understood without first exploring the resistance theory.

\section{The concept, foundations and evolution of the theory of resistance}

Finlay defines resistance as "an attempt to thwart the established governmental authority in a state, challenging its attempts to rule and diminishing its political power, by means other than those afforded by the state through its normal constitutionally mandated processes (in the courts, legislature, and so on)". ${ }^{16}$ From a historical perspective, the right to resist oppression and tyranny dates back to the Enlightenment period. Political scientists and philosophers of the time were in agreement about the necessity of such a right, the

15 Popular upheavals include those in Burkina Faso in 2014, Burundi in 2015, Democratic Republic of Congo in 2016-17 and an attempted coup in Burundi in 2015 amid a political crisis. On Burkina Faso, see A Soma "Réflexion sur le changement insurrectionnel au Burkina Faso" [Reflection on the insurrectional change in Burkina Faso] (2015) 1 Revue CAMES, Sciences Juridiques et Politiques 1. On Burundi, see TV Acker "Understanding Burundi's predicament" (2015) 11 Africa Policy Brief (Egmont Papers) 1.

Finlay Terrorism and the Right to Resist, above at note 8 at 20. 
justification being that humans have abdicated the beastly state of nature where a "man is a wolf to man"17 to live in society. Life in society is predicated on respect for rules agreed upon by everybody. This "social contract" should then be upheld for the betterment of every member of society. Therefore, the only raison d'être for governments is to ensure harmony and stability based on respect for the rules. In this regard, governments themselves have to abide by the same rules. Any authorities' conduct disregarding the rules can trigger the right to resist oppression and tyranny. For Locke, "[w] herever law ends, tyranny begins, if the breach of the law brings harm to someone else; and anyone in authority who exceeds the power given him by the law, using the force at his disposal to do to the subject things that aren't allowed by the law, thereby stops being an officer of the law; and because he acts without authority he may rightly be opposed, as may any other man who by force invades the right of someone else". ${ }^{18}$ For Jean-Jacques Rousseau,

“... all private persons return to their first equality, because they are nothing; and, subjects having no law but the will of their master, and their master no restraint but his passions, all notions of good and all principles of equity again vanish. There is here a complete return to the law of the strongest, and so to a new state of nature, differing from that we set out from; for the one was a state of nature in its first purity, while this is the consequence of excessive corruption. There is so little difference between the two states in other respects, and the contract of government is so completely dissolved by despotism, that the despot is master only so long as he remains the strongest; as soon as he can be expelled, he has no right to complain of violence. The popular insurrection that ends in the death or deposition of a Sultan is as lawful an act as those by which he disposed, the day before, of the lives and fortunes of his subjects. As he was maintained by force alone, it is force alone that overthrows him."19

The resistance theory has permeated the human rights terrain. It is no surprise that, under the influence of the revolutionary ideas of the Enlightenment philosophers referred to above, the French Declaration of Rights of Man and the Citizen of 1789 provided for the right of resistance to oppression. ${ }^{20}$ According to Heyns, "[h]uman rights is the flipside of the coin

17 "To speak impartially, both sayings are very true: that man to man is a kind of God; and that man to man is an arrant wolf' (emphasis original): T Hobbes De Cive (2000, InteLex Corporation) at 21, available at: <http://pm.nlx.com/xtf/view?docId=hobbes/hobbes.01.xml;chunk.id=div. britphil.v2.5;toc.depth=2;toc.id=div.britphil.v2.1;brand=default $>$ (last accessed 19 February 2019).

18 J Locke Second Treatise of Government (1689, Awnsham Churchill) at 202.

19 J-J Rousseau The Social Contract \& Discourses (1920, JM Dent \& Sons) at 234.

20 Declaration of the Rights of Man and Citizen, approved by the National Assembly of France, 26 August 1789, art 2: "The aim of all political association is the preservation 
of legitimate resistance". ${ }^{21}$ For Finlay, "human rights may be viewed as the expressions of resistance ... [because] ... articulating them may even be itself an act of resistance as is certainly their self-conscious exercise in the face of a state that tries to deny them". ${ }^{22}$

Therefore, the inalienable or sacred nature of human rights entitles the holders to resist whenever the rights are violated, because "human rights are not about asking favours and they are not merely moral or rhetorical concepts; they are guides to action and triggers of resistance against what is perceived as the illegitimate use of power, in particular state power". ${ }^{23}$ Hence, the concept of human rights constitutes a powerful guarantee against the abuse of political power and challenges its illegitimate use, at least at a theoretical level. ${ }^{24}$ For Forst, human rights are "first and foremost weapons in combating certain evils that human beings inflict upon one another". ${ }^{25}$ Although they "do not specify a fixed threshold beyond which non-compliance by any regime renders it liable to resistance", ${ }^{26}$ human rights nonetheless "exemplify the type of principles the violation of which may trigger a justification for resistance". ${ }^{27}$

From this perspective, "[h]uman rights are designed as struggles". ${ }^{28}$ Okafor and Ugochukwu argue that struggle is conceived as "a process of mobilizing and expressing opposition to the effects of power on the identities, interests and needs of subordinated groups". ${ }^{29}$ It alludes to political mobilization and organization to express and promote demands that are in keeping with widening political participation, and the promotion of socio-economic equality. ${ }^{30}$ In terms of human rights, there is no given right; every right is a conquered one. Throughout history, Africans have waged numerous struggles in the name of their dignity, freedoms and rights. Cheru identified four main phases of political struggle: "1) the struggle for independence from colonial rule; 2) the post-independence experience with development and nation

contd

of the natural and imprescriptible rights of man. These rights are liberty, property, security, and resistance to oppression."

21 C Heyns "A 'struggle approach' to human rights" in A Soeteman (ed) Pluralism in Law (2001, Kluwer Academic Publishers) 171 at 171.

22 Finlay Terrorism and the Right to Resist, above at note 8 at 29.

23 Heyns "A 'struggle approach", above at note 21 at 171.

24 Finlay Terrorism and the Right to Resist, above at note 8 at 29.

25 R Forst Justification and Critique: Towards a Critical Theory of Politics (2014, Polity Press) at 70; see also Finlay, ibid.

26 Finlay, id at 28.

27 Id at 26.

28 OC Okafor and B Ugochukwu "Inventing legal combat: Pro-poor 'struggles' in the human rights jurisprudence of the Nigerian appellate courts, 1999-2011" (2014) 7 African Journal of Legal Studies 429 at 431 .

29 Id at 432.

30 G Harrison "Bringing political struggle back in: African politics, power \& resistance" (2001) 28/89 Review of African Political Economy 387 at 387. 
building; 3) the post-1980 experience with market-oriented economic reform, under the 'benevolent' guidance of the IMF and the World Bank; and 4) the post-1990 experience with multiparty democracy". ${ }^{31}$ These struggle instances have had profound implications for democracy and the protection of Africans' dignity and human rights. From this, one notices that resistance is prima facie justifiable in the face of gross injustices, such as instances of "unjust harms, unjust discrimination, and unjust domination". ${ }^{22}$ Given this state of affairs, a critical question arises as to whether there is a right under international or African law to resist gross undemocratic practices.

\section{The right to resist in international human rights law}

In international human rights law, the legal basis for the right to resist oppression and tyranny is doubtful. The Universal Declaration on Human Rights (UDHR) is the oft-cited source for the right to resist. Paragraph 3 of its preamble states that "whereas it is essential, if man is not to be compelled to have recourse, as a last resort, to rebellion against tyranny and oppression, that human rights should be protected by the rule of law". ${ }^{33}$ This preambular paragraph requires a political system based on the rule of law to ensure that human rights and freedoms are duly respected. Tyranny, dictatorship and oppression are inimical to human rights. In fact, they leave the door wide open for rights holders actively to resist and rebel against such systems. That paragraph read together with other rights enshrined in the declaration related to self-determination and popular participation ${ }^{34}$ led some authors to find the legal foundation of the right to resist within the UDHR. For Paust, the right to resist ${ }^{35}$ today "is an important international precept and a part of available strategies for the assurance both of the authority of the people as the lawful basis of any government and of the process of national selfdetermination". ${ }^{36}$ However, the position is not so clear-cut. Contemporary authors like Murphy rightly affirm that the UDHR does not provide for a right to resist. For him, "the form of its wording and its placement in a preambular position rather than as anticle and thus without direct effect,

31 F Cheru "Democracy and people power in Africa: Still searching for the "political kingdom”" (2012) 33/2 Third World Quarterly 265 at 268.

32 Finlay Terrorism and the Right to Resist, above at note 8 at 24.

33 UDHR, GA res 217(III)A, UN doc A/RES/217(III) (10 December 1948), preamble.

$34 \mathrm{Id}$, arts 20 and 21.

35 Prof Paust calls it the "right to revolution": JJ Paust "The human right to participate in armed revolution and related forms of social violence: Testing the limits of permissibility" (1983) 32 Emory Law Journal 545 at 562. However, a revolution challenges the established order, while resistance to oppression is not necessarily revolutionary. On the contrary, it is conservative in the sense of this article since its purpose is to restore the constitutional order, ie a return to the status quo ante as the French Constitutionalist Burdeau put it; see G Burdeau Traité de Science Politique [Treatise on political science], vol III (1950, Librairie Générale de Droit et de Jurisprudence) at 492.

Paust "The human right", ibid. 
suggest that [the right to resist] is actually formulated as a non-right" ${ }^{37}$ Moreover, according to the travaux préparatoires, proposals that were made in support of a right to resist were ultimately not adopted. For instance, article 29 of John Humphrey's draft stipulated that "[e]veryone has the right, either individually or with others, to resist oppression and tyranny". ${ }^{38}$ Similarly, article 25 of René Cassin's draft provided that "[w]henever a government seriously or systematically tramples fundamental human rights and freedoms, individuals and peoples have the right to resist oppression and tyranny, without prejudice to their right of appeal to the United Nations". ${ }^{39}$ Despite the clear inclination of these UDHR forefathers for a right to resist, no such right is actually enshrined in the declaration.

Since then, there has been no new attempt to enshrine such a right, despite the opportunities presented by the drafting processes of the major international human rights instruments. ${ }^{40}$ However, some tentative steps have been made at the UN level. For example, the UN Resolution on Human Rights Defenders provides that "[e]veryone has the right, individually and in association with others, to participate in peaceful activities against violations of human rights and fundamental freedoms". ${ }^{41}$ Quite recently, an earlier version of the Draft Declaration on the Right to Peace by the UN Human Rights Council (HRC) provided, under the title "Resistance and opposition to oppression", that:

"1. All peoples and individuals have the right to resist and oppose oppressive colonial, foreign occupation or dictatorial domination (domestic oppression).

2. Everyone has the right to oppose aggression, genocide, war crimes and crimes against humanity, violations of other universally recognized human rights, and any propaganda in favour of war or incitement to violence and violations of the right to peace ..." ${ }^{42}$

37 S Murphy "The right to resist reconsidered" in D Keane and Y McDermott (eds) The Challenge of Human Rights Past, Present and Future (2012, Edward Elgar) 91 at 95.

38 John Humphrey's draft is available at: <http://biblio-archive.unog.ch/detail.aspx?ID= 27373> (last accessed 11 December 2018).

39 René Cassin's draft is available at: <http://biblio-archive.unog.ch/detail.aspx?ID=27373> (last accessed 11 December 2018).

40 For example: Convention on the Prevention and Punishment of the Crime of Genocide (1948); International Convention on the Suppression and Punishment of the Crime of Apartheid (1973); Convention against Torture and Other Cruel, Inhuman or Degrading Treatment or Punishment (1984); International Covenant on Civil and Political Rights (1966); International Covenant on Economic, Social and Cultural Rights (1966).

41 Declaration on the Right and Responsibility of Individuals, Groups and Organs of Society to Promote and Protect Universally Recognized Human Rights and Fundamental Freedoms, UN GA res 53/144 (9 December 1998), UN doc A/RES/53/144 art 1 (UN Declaration on Human Rights Defenders).

42 HRC Report of the Human Rights Council Advisory Committee on the Right of Peoples to Peace (16 April 2012), UN doc A/HRC/20/31, art 7. 
Ultimately, this provision did not become a consecrated right in the final text of the declaration. ${ }^{43}$

From this survey, one can conclude that no norm on the right to resist has so far crystallized at the global level. All the steps taken at the time of the UDHR or later simply failed or were tentative. This contrasts with the African experience.

\section{The right to resist in African law}

The African human rights system does provide for the right to resist. This prerogative can be inferred from article 20 of the African Charter on Human and Peoples' Rights (African Charter), which states that "all peoples ... shall have the unquestionable and inalienable right to self-determination". ${ }^{44}$ The right to self-determination implies, inter alia, that peoples "shall freely determine their political status and shall pursue their economic and social development according to the policy they have freely chosen". ${ }^{45}$ Consequently, "[c]olonized or oppressed peoples shall have the right to free themselves from the bonds of domination by resorting to any means recognized by the international community". ${ }^{46}$ Paragraph 3 of the same article asserts that "[a]ll peoples shall have the right to the assistance of the States Parties ... in their liberation struggle against foreign domination, be it political, economic or cultural". ${ }^{47}$

It is thus clear that this provision codifies the right to resist foreign as well as domestic oppression or domination, since it refers not only to "colonized peoples" but also to "oppressed peoples" within Africa. In fact, the drafters of the African Charter were not only concerned by the impact of colonization and foreign domination on the rights of African peoples but also by the negative impact of tyranny and despotism of post-colonial African regimes, including those of Idi Amin in Uganda, Emperor Bokassa in Central African Republic and Sékou Touré in Guinea. ${ }^{48}$ However, no African human rights enforcement mechanism has so far made such a finding or a declaration that article 20 can provide the legal basis for the right to resist. Nevertheless, the African human and peoples' rights mechanisms have already determined that peoples who are entitled to self-determination include sub-groups within the population of a member state. ${ }^{49}$ Henceforth, the former can also claim self-determination

43 HRC Declaration on the Right to Peace, A/HRC/RES/32/28 (1 July 2016).

44 African Charter, art 20(1).

45 Ibid.

46 Id, art 20(2).

47 Id, art 20(3).

48 E Kodjo "The African Charter on Human and Peoples' Rights" (1990) 11 Human Rights Law Journal 271 at 281-82, cited by S Murphy "Unique in international human rights law: Article 20(2) and the right to resist in the African Charter on Human and Peoples' Rights" (2011) 11/2 African Human Rights Law Journal 465 at 474.

49 Centre for Minority Rights Development (Kenya) and Minority Rights Group (on behalf of the Endorois Welfare Council) v Kenya comm 276/03, African Commission on Human and Peoples' Rights, 25 November 2009, para 255; Front for the Liberation of the State of 
as a way to resist internal oppression and domination. ${ }^{50}$ However, this form of self-determination can only be exercised within the territorial confines of the state, ${ }^{51}$ since "secession is not recognised as a variant of the right to selfdetermination within the context of the African Charter". ${ }^{2}$ However, outside the realm of the doctrine of the responsibility to protect provided for in article 4(h) of the AU Constitutive Act, sub-groups within a state cannot enjoy the right (provided for in article 20(3)) to assistance from states parties in their struggle, since their struggle is not waged against foreign aggression and domination.

The ACDEG did not expand on these provisions of the African Charter. It only requires member states to ensure that enabling conditions for democratic rule are in place and that rights holders do enjoy the rights enshrined in them. For instance, article 4 requires "State Parties to commit themselves to promote democracy, the principle of the rule of law and human rights [and to] recognize popular participation through universal suffrage as the inalienable right of the people". ${ }^{53}$ Article 5 emphasizes the importance of, and the duty to uphold, constitutional rule, particularly the constitutional transfer of power. In this regard, the ACDEG clearly proscribes unconstitutional changes of governments. ${ }^{54}$ However, there is no express right allowing people to resist gross undemocratic practices that amount to violations of their democratic rights. The only express call is made to the AU to intervene in a member state in the case of an unconstitutional change of government. Article 24 of the ACDEG provides that "(w)hen a situation arises in a State Party that may affect its democratic political institutional arrangements or the legitimate exercise of power, the Peace and Security Council shall exercise its responsibilities in order to maintain the constitutional order in accordance with relevant provisions of the Protocol Relating to the Establishment of the

contd

Cabinda $v$ Republic of Angola comm 328/06, African Commission on Human and Peoples' Rights, November 2013, para 131; African Commission on Human and Peoples' Rights $v$ The Republic of Kenya (Ogiek) appln 006/2012, African Court on Human and Peoples' Rights, judgment of 26 May 2017, para 199.

50 Oppression and domination were identified as the two conditions to be met in order to substantiate a violation of article 20 in Kevin Mgwanga Gunme et al v Cameroon comm 266/03, African Commission on Human and Peoples' Rights, 27 May 2009, para 197.

51 In the Katanga case, the African Commission held that "Katanga is obliged to exercise a variant of self-determination that is compatible with the sovereignty and territorial integrity of Zaire": Congrès du Peuple Katangais v République du Zaire comm 75/92, African Commission on Human and Peoples' Rights, 22 March 1995, para 6. In the Ogiek judgment of May 2017, the African Court held that sub-groups of the population do enjoy charter rights, especially the right to self-determination, "provided such groups or communities do not call into question the sovereignty and territorial integrity of the State without the latter's consent”; see Ogiek, above at note 49, para 199.

53 ACDEG, art 4(1)(2).

54 Id, art 23. 
Peace and Security Council of the African Union". 55 The amended article 4(h) also recognizes the AU's right to intervene in the case of a serious threat to legitimate order to restore peace and stability to the member state. ${ }^{56}$ However, this amendment is not yet in force. Thus the AU's potential right to intervene in an ACDEG state party facing a constitutional crisis, especially an unconstitutional change of regime, is still remote. One has to acknowledge that the AU has nevertheless developed a sustained practice to impose sanctions against persons or groups responsible for an unconstitutional change of government situation. Sanctions vary from denunciation to the suspension of the member state from the AU. ${ }^{57}$ The moral and political justification for the AU's right to intervene in internal matters lies in the fact that unconstitutional changes of government are deemed to be the main obstacles to the establishment of democratic rule based on the supremacy of the constitution in Africa. They are also "the essential causes of insecurity, instability and violent conflict in Africa". ${ }^{58} \mathrm{AU}$ intervention in those situations is not tantamount to giving assistance to peoples struggling against tyranny referred to in article 20(3) of the African Charter. In fact, the peace and security paradigm underpins interventions to the point that the rationale behind them is not about assisting peoples per se, but ensuring the maintenance of constitutional order and political stability, ${ }^{59}$ even if this means maintaining a ruthless regime in power!

However, even if the ACDEG does not provide for an express right to resist per se, it should be noted that the charter is like an additional instrument to the African Charter, as it expands and determines the conditions and parameters for the enjoyment of the right to participate in public affairs enshrined in article 13 of the African Charter. The two instruments are therefore linked in a certain way. One can hope that the ACDEG will be interpreted in a way compatible and consonant with articles 13 and 20 of the African Charter, in order to provide a legal basis for the right to resist gross undemocratic

55 Id, art 24. See also IK Souaré The PSC and Unconstitutional Changes of Government in Africa: A Critical Assessment (2009, Institute for Security Studies). The AU intervened in Comoros in 2008 with Operation Democracy in the Comoros, aimed at restoring the constitutional order in Comoros with military, logistical and financial support from Tanzania, Sudan, Libya and Senegal. The operation helped to prevent a looming unconstitutional change of government in the country.

56 In addition to war crimes, genocide and crimes against humanity, art 4(h) of the Protocol on Amendments to the Constitutive Act of the African Union (Maputo, 2003) recognizes the AU's right to intervene in a member state in the case of a serious threat to legitimate order, in order to restore peace and stability to the member state upon the recommendation of the AU Peace and Security Council (PSC).

57 For a complete review of possible sanctions, see P Manirakiza "Insecurity implications of unconstitutional changes of government in Africa: From military to constitutional coups" (2016) 17/2 Journal of Military and Strategic Studies 86.

58 ACDEG, preamble, para 8 and arts 4 and 23.

59 E Baimu and K Sturman "Amendment to the African Union's right to intervene" (2003) 12/2 African Security Review 37 at 43-44. 
practices. At a minimum, the application and interpretation of the ACDEG should uphold the jurisprudence of the African Court and Commission on Human and Peoples' Rights on the matter of popular participation.

At the state level, some African countries have constitutionalized the right to resist gross undemocratic practices. For instance, the Constitution of the Democratic Republic of Congo provides for citizens to have the duty to oppose any individual or a group of individuals willing to seize power by force or to exercise it in violation of the constitution. ${ }^{60}$ Similarly, an attempted coup against the constitutional order is a crime against the nation and the state. ${ }^{61}$ The Constitution of the Republic of Uganda provides for a right and a duty on Ugandans, at all times, "to defend this Constitution, and in particular, to resist any person or group of persons seeking to overthrow the established constitutional order" 62 and "to do all in their power to restore this Constitution after it has been suspended, overthrown, abrogated or amended contrary to its provisions". ${ }^{63}$ Paragraph 5 of the same provision immunizes, from criminal proceedings, any person or group of persons who resists the suspension, overthrow, abrogation or unconstitutional amendment of the constitution. Similarly, but in less stringent terms, the constitutions of Mali, Burkina Faso and Benin provide a constitutional right for citizens to engage in civil disobedience in order to resist unconstitutional changes of government or attempted changes of government, and / or to restore constitutional legitimacy. ${ }^{64}$ In Benin for instance, in the case of a coup d'état, putsch or aggression, civil disobedience is not only a sacred right but also an imperative duty for Beninese citizens. ${ }^{65}$

60 Constitution of the Democratic Republic of Congo, art 64: "Every Congolese has the duty to defeat any individual or group of individuals who seizes power by force or who exercises it in violation of the provisions of this Constitution. Any attempt to overthrow the constitutional system constitutes an offence against the nation and the state, to which no statute of limitations applies. It is punished according to the law." (Author's translation).

61 Ibid.

62 Uganda Constitution, 1995, art 3(4)(a).

$63 \mathrm{Id}$, art 3(4)(b).

64 Constitution of the Republic of Mali, art 121: "The people have the right to civil disobedience for the preservation of the republican form of the state. The source of all legitimacy derives from this Constitution." (Author's translation). Constitution of Burkina Faso, art 167: "Any power that does not originate from this Constitution, especially that resulting from a coup d'état or a putsch, is illegal. In this case, the right to civil disobedience is recognized for all citizens." (Author's translation). Constitution of the Republic of Benin, art 66: "In the event of a coup d'état, putsch, aggression by mercenaries or any coup de force, any member of a constitutional body has the right and the duty to use all means to restore constitutional legitimacy, including resorting to existing military or defence cooperation agreements. In these circumstances, for every Beninese, disobeying and organizing to defeat the illegitimate authority is the most sacred of rights and the most imperative duty." (Author's translation).

Constitution of the Republic of Benin, art 66. 
Although provisions that constitutionalize the right to resist gross undemocratic practices can be found in the constitutions of the different countries alluded to above, there are no reported cases or instances where peoples have actually invoked and effectively exercised this right to resist, despite the fact that constitutions are easily manipulated in countries such as the Democratic Republic of Congo and Uganda, in a bid for the incumbents to remain in power. The only instance to mention is the case of Burkina Faso, where civil society and opposition political parties resorted to article 167 of the constitution to find a legal basis for the 2014 popular uprising followed by a coup d'état and the subsequent regime change. ${ }^{66}$ However, some authors posit, on the basis of article 23 of the ACDEG, that the toppling of the Compaoré regime was an unconstitutional change of government, since the change was effected not by popular insurrection (which had been unsuccessful), but a subsequent military coup led by Lieutenant-Colonel Yacouba Isaac Zida. ${ }^{67}$

The right to resist undemocratic practices in Africa is taking shape alongside other democratic rights. From its consecration in the African Charter, the right is slowly gaining constitutional recognition in the constitutions of some AU member states, as highlighted above. In fact, democratic rights are key; African citizens who are deprived of these rights should have access to remedies through democratic institutions and the court system, as provided for in constitutions. If the system is dysfunctional or paralysed, they can resort to their right to resist in order to ensure protection of their rights. At the end of the day, as highlighted above, human rights are only realized by the struggles of real people experiencing real instances of domination ${ }^{68}$ and oppression. Citizens therefore need to be empowered.

\section{EMPOWERING AFRICANS AND RAISING AFRICANS' DEMOCRATIC AGENCY TO RESIST GROSS UNDEMOCRATIC PRACTICES}

Given Africans' keen interest in the rule of law and good governance, which are purportedly supportive of better protection for their rights, they should be empowered to resist undemocratic practices. Why is it so important for African citizens to be empowered in this regard? When and how should they justifiably resist gross undemocratic practices? What are the constraints to the effective exercise of the right to resist? The last part of this article deals with these important questions.

66 Soma "Réflexion sur le changement", above at note 15 at 4-5.

67 SM Ouedraogo and D Ouedraogo "Libres propos sur la transition politique au Burkina Faso: Du contexte au texte de la Charte de la Transition" [Comments on the political transition in Burkina Faso: From context to the text of the Transitional Charter] (2015) 1 Revue Sciences Juridiques et Politiques (CAMES) 1 at 6-7.

68 A Belden Fields and W-D Narr "Human rights as a holistic concept" (1992) 14 Human Rights Quarterly 1 at 5. 


\section{Rationale for empowering Africans with the right to resist gross undemocratic practices}

Historically, African peoples and individuals have resisted oppression and domination. For instance, they resisted colonial rule and this resistance led to the independence of all African nations from foreign domination. In postindependence Africa, resistance culminated in the affirmation of important democracy-related human and peoples' rights, which are today mostly enshrined in the ACDEG. However, in the past, African peoples have not necessarily or massively resisted the deprivation of their rights in other contexts. Many factors can explain such an attitude, including: fear of reprisals under fierce and oppressive regimes; lack of means and resources to challenge the power of the state or society effectively; the colonial legacy that imposed a new form of government and new structures alien to the traditional way of governance; ignorance of rights; lack of a clear constitutional or legal basis to found resistance; and other imperative priorities such as fulfilling their basic needs. In these circumstances, victims of human rights violations in a sense become complicit in their own fate, which deprives them of their agency to resist anti-democratic practices. One author describes this phenomenon in terms of the theory of "false consciousness", in which victims of a social problem seem to support mechanisms and practices that are inimical to their own interests and agendas. ${ }^{69}$ In some countries for instance, citizens' blind obedience leads them to partake in demonstrations in favour of the ruling party or their "beloved" leader or guide, during which they vociferate insults or hate messages towards opposition leaders or civil society organizations accused of being puppets of foreign interests ${ }^{70}$ or even international institutions. ${ }^{71}$

It should be kept in mind that, merely because victims of human rights abuses may, at a certain time, be powerless to act and resist poor living conditions, it does not mean that they cannot ever be roused to challenge or overcome them. ${ }^{72}$ Gradually, they can become conscious of their fate and decide to organize themselves and protest against their conditions or the situation arising out of unconstitutional conduct by way of popular uprisings or coups d'état. Mobilization is usually not done by genuine peoples' organizations but by civil society organizations and opposition political parties that, most of the time, are motivated more by political gains than by the best interests of the people. In Burkina Faso for instance, major civil society organizations and opposition parties took the lead of the movement Balai Citoyen that was waged against the government of former President Blaise

69 S Mahmood Politics of Piety: The Islamic Revival and the Feminist Subject (2005, Princeton University Press) at 2.

70 Pro-government demonstrations in Burundi very often accuse opposition and civil society leaders of working in tandem with and in the interests of Rwanda and the European Union.

71 Such as demonstrations against the International Criminal Court in Sudan and Burundi.

72 Mahmood Politics of Piety, above at note 69 at 15. 
Compaoré. Former President Compaoré had sought to change the constitution in order to vie for another presidential term. The people of Burkina Faso successfully resisted the move, forcing him out of office with the intervention of the army, which orchestrated a coup. After a successful transition, an elected government is in place and, by and large, citizens seem to enjoy their political and civil rights. In Burundi, the movement Halte au 3ème Mandat was a product of civil society mainstream organizations and opposition political parties, along with dissidents from the ruling party CNDDFDD. Some unhappy military forces also joined and staged an unsuccessful military coup d'état on 13 May 2015. After the failure of the attempted coup, subsequent demonstrations were severely quashed by security forces loyal to the Nkurunziza regime. ${ }^{73}$

These recent popular uprisings in Africa are to be located within the "struggle" dimension of human rights protection. In fact, one writer characterizes them as "Africa's second independence". ${ }^{74}$ As far as the right to democracy is concerned, the struggle process consists of mobilizing efforts and other means in order to resist an antidemocratic gross move by an incumbent government or other political entities, such as the military plotting a coup d'état.

Two compelling reasons justify why African peoples should be empowered to resist gross undemocratic practices. First, Africans are usually expected to operate changes of governments through elections, not through revolutions. In the situation of gross undemocratic practices, governments are no longer law-abiding entities, or they manipulate the law and seek its interpretation in a way favourable to their political interests, which enable them to stay in power. In these frequent instances, African peoples are powerless and have no real say to change the situation. The ACDEG and the AU Constitutive Act expressly empowered the AU, not the African peoples, to resist undemocratic practices threatening or breaking the constitutional order. ${ }^{75}$ If states with a primary responsibility to protect individual and peoples' rights are either unwilling or unable to do so and the AU fails to intervene when legally necessary and justifiable, then rights holders can take the matter into their hands and fight for their dignity, integrity and equality. As has been demonstrated in the examples of popular uprisings throughout Africa, African citizens do count, socially and politically; they can be the agents of their own fate. In the author's view, they constitute the second pillar, along with AU, in the resistance against gross undemocratic practices.

Secondly, the nature of the right to resist is highly empowering. In principle, most human and peoples' rights impose limits on state authority and

73 HRC Report of the Commission of Inquiry on Burundi, 36th session 11-29 September 2017, UN doc A/HRC/36/54, para 29; Report of the Delegation of the African Commission on Human and Peoples' Rights on its Fact-finding Mission to Burundi, 7-13 December 2015, paras 64, 65, 149 and 160.

74 Cheru "Democracy and people power", above at note 31 at 266.

75 ACDEG, art 24; AU Constitutive Act, art 4(h). 
enjoin state governments what to do or not to do in order to promote and protect rights. The right to resist is of a different nature. Within the African context, Murphy presents the right to resist as a mode of implementation and enforcement of the body of human rights, an effective remedy against violations, a deterrent to violator regimes within human security frameworks, and a complement or alternative to the "responsibility to protect". ${ }^{76}$ Ginsburg reinforces the point that "the right to resist is distinct from other rights because of its second-order character. That is, rather than provide a particular substantive limit on State authority, the right to resist serves as an enforcement mechanism to protect other constitutional rights". 77 For Honoré, the right to resist is a secondary right that "exists only when a wrong has been committed. Its point is to provide a remedy in the event of the violation on a large scale of primary rights". ${ }^{78}$ Without the right to resist, other rights would be dead letter and could not be effective. ${ }^{79}$

The right to resist is henceforth a tool to ensure the enjoyment of democratic rights; it is also a constant reminder to the authorities that power belongs to the people and that human rights do matter. In a nutshell, on a conceptual plan, the right to resist is a right-remedy invoked and exercised when primary democratic rights have been violated. However, important as it is, the right to resist should not be construed in such a way that it bypasses state action. The right to resist must recognize, give precedence to and yield in favour of the state, which has the primary responsibility to protect human rights in accordance with current international human rights law. Therefore, if democratic norms are respected or if violations of democratic rights have been remedied by the state, then the right to resist does not arise. Finally, being a right-remedy and a "supreme human right" as Lauterpacht labels it, ${ }^{80}$ the right to resist would be an excellent tool in the hands of African citizens when neither states nor the AU are willing to remedy a situation characterized by gross undemocratic practices.

\section{Threshold and parameters for the right to resist}

\section{The test}

The threshold to invoke the super-right to resist is not clear. In general, African citizens can invoke the right to resist as a last resort, "only in the most extraordinary circumstances of illegitimate government action". ${ }^{81}$ What constitutes illegitimate government action is not clearly defined. In

76 Murphy "Unique in international human rights law", above at note 48 at 494.

77 T Ginsburg, D Lansberg-Rodriguez and M Versteeg "When to overthrow your government: The right to resist in the world's constitutions" (2013) 60/5 UCLA Law Review 1184 at 1190.

78 T Honoré "The right to rebel" (1988) 8/1 Oxford Journal of Legal Studies 34 at 38.

79 JF Spitz "Le droit de résistance" [The right to resist] in P Raynaud and S Rials (eds) Dictionnaire de Philosophie Politique (2003, Presses Universitaires de France) 169 at 169.

80 H Lauterpacht International Law and Human Rights (1950, Stevens and Sons) at 116.

81 Ginsburg et al "When to overthrow your government", above at note 77 at 1190 . 
keeping with the scope of this article, at least two situations could trigger the right to resist. The first coincides with that of unconstitutional changes of government or attempted changes. As the AU understands it, an unconstitutional change of government implies, inter alia, any of the following illegal means of accessing or maintaining power:

\begin{abstract}
“[A]ny putsch or coup d'Etat against a democratically elected government; any intervention by mercenaries to replace a democratically elected government; any replacement of a democratically elected government by armed dissidents or rebels; any refusal by an incumbent government to relinquish power to the winning party or candidate after free, fair and regular elections; or any amendment or revision of the constitution or legal instruments, which is an infringement on the principles of democratic change of government". ${ }^{82}$
\end{abstract}

Secondly, a situation of massive or serious human rights violations can also trigger the implementation of the right to resist. The serious or massive nature of violations can be duly evinced by reports from competent entities such as human rights fact-finding missions carried out by the African Commission on Human and Peoples' Rights or the Office of the High Commissioner for Human Rights. ${ }^{83}$ During the uprisings in the African Maghreb, citizens of Egypt and Tunisia successfully resisted the oppressive and dictatorial regimes of Presidents Mubarak and Ben Ali respectively. At the time, the situation in those countries was characterized by serious human rights violations. ${ }^{84}$

The resistance test set out above is high. The ensuing thorny issue relates to how the right to resist should be exercised. First of all, in the case of gross undemocratic practices, it is imperative to recall that resistance can only be mounted when constitutionally mandated accountability institutions such as the human rights commissions, the media or others have been weakened, suborned or corrupted ${ }^{85}$ or, in the case of courts, are not available, accessible

82 ACDEG, art 23.

83 For Burundi, see Report of the UN Commission of Inquiry on Burundi, A/HRC/36/54 (2017); Report of the United Nations Independent Investigation on Burundi (UNIIB) Established Pursuant to Human Rights Council Resolution S-24/1, A/HRC/33/37 (2016); Report of the Delegation of the African Commission on Human and Peoples' Rights on its Fact-Finding Mission to Burundi (December 2015).

84 Human Rights Watch "World report 2011: Egypt", available at: <https://www.hrw. org/world-report/2011/country-chapters/egypt> (last accessed 11 December 2018); Human Rights Watch "World report 2011: Tunisia”, available at: <https://www.hrw. org/world-report/2011/country-chapters/tunisia> (last accessed 11 December 2018).

85 S Adejumobi "Unbundling liberal democracy: Institutions, participation and accountability" in S Adejumobi (ed) Voice and Power in Africa's Democracy: Institutions, Participation and Accountability (2017, Routledge) 1 at 2; see also Cheru "Democracy and people power", above at note 31 at 283. 
or sufficient. ${ }^{86}$ In such cases, resistance against gross undemocratic practices can take different forms.

\section{Forms of resistance}

Resistance against gross undemocratic practices can be moderate or radical, ${ }^{87}$ depending on the circumstances.

Moderate resistance encompasses actions aimed at challenging a particular state's actions, policies or programmes ${ }^{88}$ in the absence of alternative means, or when there are ostensibly weak and ineffective democratic institutions and structures that leave citizens with no effective mechanisms for resolving their grievances. People resorting to moderate forms of resistance invoke constitutionally guaranteed rights in order to ensure respect for and protection of other rights. For instance, freedom of expression allows a right holder to express his or her views, whatever form they take, provided they are within the confines of the law, in order to voice opinions on matters of interest. Similarly, freedom of assembly enables individuals to descend into the streets to protest against gross undemocratic practices; massive demonstrations can paralyse the political and socio-economic life of a nation, even if there is no use of violence. Moreover, some will argue that resorting to judicial or quasijudicial proceedings is another form of moderate resistance, in the sense that a complaint lodged before a court or quasi-judicial entity intends primarily to denounce conduct that violates human rights and seeks to remedy the situation. Ultimately, the legitimacy of the right to resist requires citizens to oppose unjust laws only within the system, using avenues that the system leaves open. ${ }^{89}$

Moderate resistance actions do not necessarily lead to structural changes. Nonetheless, they are an important means for challenging government action and imposing restraints on power. ${ }^{90}$ Usually, moderate resistance does not resort to violence; it uses soft means. Some means are law-abiding actions such as mass mobilizations, lobbying and peaceful demonstrations, while others are law-defiant, such as civil disobedience, which may imply protests against obeying certain laws ${ }^{91}$ for the greater good of challenging injustices. According to the International Service of Human Rights reading of the UN Declaration on Human Rights Defenders, "any actions taken by human rights defenders must be peaceful. Violence cannot be used to protect or promote

86 Sir Dawda K Jawara $v$ Gambia (The) comm 147/95-149/96, African Commission on Human and Peoples' Rights, 11 May 2000, para 31.

87 Finlay Terrorism and the Right to Resist, above at note 8 at 21. For Cheru, the struggle for democracy can take "the form of visible and invisible resistance, including armed struggle": Cheru "Democracy and people power", above at note 31 at 282.

88 Finlay, ibid.

89 P Pettit "Legitimacy and justice in republican perspective" (2012) Current Legal Problems 65 at 65.

90 Cheru "Democracy and people power", above at note 31 at 283.

91 Finlay Terrorism and the Right to Resist, above at note 8 at 78. 
human rights under any circumstances".92 Article 20(2) of the African Charter grants peoples the right to resist inasmuch as they resort to any means recognized by the international community. For Murphy, this has the positive effect of ensuring that the right is exercised in a manner generally consistent with international human rights law, international humanitarian law and international criminal law as they stand at any given time. ${ }^{93}$

The exercise of the right to resist should remain fully consistent with the principle of respect for the rule of law, which generally proscribes the use of violence. Consequently, "if the right to resist is properly exercised, the state has a duty not to repress those engaged in it. Such repression might conceivably lead to criminal liability, either on the international plane or in local courts after a political transition, on the part of state agents that engage in such repression". ${ }^{94}$

Radical resistance entails resorting to more pressure and actions when moderate resistance has led nowhere. As Cheru wrote, "when oppressed people are denied the opportunity to bring change through peaceful means, they will not hesitate to pick up arms as a last resort". ${ }^{95}$ Radical resistance implies the use of violence, the appropriate degree of which is not legally determined. Finlay posits that armed resistance is triggered by "the use of violence by the state itself or the infliction of equivalent harms in violation of the most fundamental 'Life and Limb' rights". ${ }^{96} \mathrm{He}$ argues for "Purely Defensive Violence":

"In states where the government does not threaten violent repression, then peaceful means of protest are simply the default resort for resistance, that is, nonviolence is what ordinary, peacetime morality requires since armed resistance would simply be impermissible in the absence of prior, unjust violent threats. By contrast, once it is clear that the regime is violent, that is, either in the form of a persistent background threat of killing, torture or the equivalent or in an explicit threat of attack during or in anticipation of protests, peacefulness is not the default position. For those who are not absolute pacifists, committed on moral or religious grounds to nonviolence even in the face of lethal aggression, the default position in these circumstances is Purely Defensive Violence, that is, it is permissible for individuals to defend themselves using necessary and proportionate force and, arguably, a duty for some to use force on behalf of others where those others cannot defend themselves." 97

92 International Service for Human Rights "Defending human rights defenders: A short guide" at 4, available at: <http://olddoc.ishr.ch/hrdo/publications/WHRDbooklet_EN. pdf> (last accessed 19 February 2019).

93 Murphy "Unique in international human rights law", above at note 48 at 474.

94 Ginsburg et al "When to overthrow your government", above at note 77 at 1195.

95 Cheru "Democracy and people power", above at note 31 at 283.

96 Finlay Terrorism and the Right to Resist, above at note 8 at 314.

97 Id at 92-93. 
Contrary to moderate resistance, the objective of radical resistance is to "defeat oppression and replace it with something more just; and to defend innocent persons from state violence while doing so". ${ }^{98}$

The legality of the use of offensive violence is rather problematic though its legitimacy is not, at least for people involved in the struggle. Circumstances will usually justify or legitimize the kind of means used during the resistance. In the case of so-called "good coups" 99 or "pro-democratic coups", ${ }^{100}$ consisting of the overthrow of rogue regimes by the use of force in the name of the restoration or the safeguard of democratic rule, the coup plotters enjoy popular support; this was the case in Niger where, in 2010, the Supreme Council for the Restoration of Democracy intervened and put an end to the existing tense political situation. ${ }^{101}$

In some instances, violence is a continuation of an unsuccessful popular upheaval although it can also trample the latter. ${ }^{102}$ Despite the fact that "good coups" may be a last resort and a legitimate solution where other means have failed, the AU does not condone them. They fit and actually fall within the AU's definition of an unconstitutional change of government if perpetrated against democratically elected governments. Of course, the problem is that a government may be democratically elected, but functions or rules undemocratically. Even in those circumstances, regime change by way of a coup d'état is still illegal in the eyes of the AU. Coups d'état do not only violate the supreme law of a country but they are also likely to cause instability. ${ }^{103}$ Not paying attention to or legitimizing some means of accession to power, such as coups d'état, as was the case under the then Organisation of African Unity (OAU), ${ }^{104}$ would be a dangerous precedent that would run

98 Id at 314

99 Ikome describes good coups "as those that are informed by a genuine desire on the part of coup-plotters to resolve unsettling societal realities, particularly in relation to poor leadership and the hardships that it brings to the people - and against the backdrop of constrained political space for peaceful change": FN Ikome "Good coups and bad coups: The limits of the African Union's injunction on unconstitutional changes of power in Africa" (2007, Institute for Global Dialogue occasional paper no 55) at 14.

100 JM Powell "An assessment of the 'democratic' coup theory: Democratic trajectories in Africa, 1952-2012" (2014) 23/3 African Security Review 213; A Trithart "Democratic coups? Regional responses to the constitutional crises in Honduras and Niger" (2013) Journal of Public and International Affairs 112.

101 Institute for Security Studies Peace and Security Council Report (no 8, March 2010) at 2, available at: <https://issafrica.s3.amazonaws.com/site/uploads/No8March_2010.pdf> (last accessed 11 December 2018). See also D Smith "Military junta seizes power in Niger coup" (19 February 2010) The Guardian, available at: <https://www.theguardian. com/world/2010/feb/19/niger-military-junta-coup> (last accessed 11 December 2018).

102 This was the case in Burundi where the 13 May 2015 attempted coup d'état halted the popular uprising.

103 MS Nkosi "Analysis of OAU / AU responses to unconstitutional changes of government in Africa" (masters thesis, University of Pretoria, April 2010) at 5.

104 See Ikome "Good coups and bad coups", above at note 99 at 16-17; also Nkosi, id at 41. Both highlight the fact that, according to the OAU's highly regarded principles of the 
counter to the democratic principles and ideals enshrined in the AU Constitutive Act and ACDEG. Accession to or maintenance of power should not be through unconstitutional means. At the same time, to expect oppressive and dictatorial regimes, controlling all levers of state power, to relinquish power and step aside appears not only idealistic, but rather naïve. That is probably why popular uprisings are not listed among unconstitutional change of governments, ${ }^{105}$ therefore recognizing popular sovereignty and the fact that citizens are at the centre of state sovereignty. The de facto recognition of popular uprisings is only valid on the presumption that they are genuine, rights-oriented, representative and conducted by those (peoples) who have the legal authority to effect change. ${ }^{106}$ Political manipulation of popular upheavals, either by civil society organizations or opposition parties, can seriously undermine their legitimacy. That is why all AU legal instruments and policy documents heavily emphasize the importance of elections, reminding us, as Obse asserts, that elections (not revolutions) are the primary means through which the people's constitutive power [pouvoir constituant] is to be expressed. ${ }^{107}$ Accordingly, "we should not be under any illusion that popular protests will serve as a substitute for elections, however popular they are". ${ }^{108}$ If popular uprisings are to effect a change of regime, this "streetocracy"109 should be treated like an unconstitutional change of government.

In the situation of freedom fighters, the question is whether all the freedom fighters' actions are legitimate and exercised in conformity with the precepts of the right to resist. History provides abundant examples of violent resistance that has nevertheless been considered legitimate. In the case of the fight against the apartheid regime in South Africa for example, Nelson Mandela and his comrades faced an untenable dilemma. During their trial, Mandela explained why it was imperative for the ANC to establish an armed wing, the Umkhonto we Sizwe:

contd

supremacy and sacrosanctity of the doctrine of sovereignty and the principle of noninterference, member states considered unconstitutional changes of government to be a matter of domestic jurisdiction not warranting OAU attention, let alone intervention.

105 The AU condoned the popular uprisings in Egypt and Tunisia; see PSC press statement PSC/PR/BR.(CDXXXII) at 2. At its 432nd meeting, the PSC held an open session, on 29 April 2014, devoted to the theme, "Unconstitutional changes of governments and popular uprisings in Africa: Challenges and lessons learnt".

106 In his "emancipatory democratic project", Cheru advocates for the transfer of power to the people through a network of peoples' organizations: Cheru "Democracy and people power", above at note 31 at 279. This view contrasts with the watchdog role assigned to civil society to check on the excesses of state power in the liberal conception of democracy: ibid.

107 K Obse "The Arab Spring and the question of legality of democratic revolution in theory and practice: A perspective based on the African Union Normative Framework" (2014) 27 Leiden Journal of International Law 817 at 836.

108 Ibid.

109 Ibid. 
“... we felt that without sabotage there would be no way open to the African people to succeed in their struggle against the principle of white supremacy. All lawful modes of expressing opposition to this principle had been closed by legislation, and we were placed in a position in which we had either to accept a permanent state of inferiority, or to defy the Government. We chose to defy the Government. We first broke the law in a way which avoided any recourse to violence; when this form was legislated against, and when the Government resorted to a show of force to crush opposition to its policies, only then did we decide to answer violence with violence." ${ }^{110}$

According to Mandela and his comrades, this kind of violence was not tantamount to terrorism because of "the ANC tradition of non-violence and negotiation as a means of solving political disputes". ${ }^{111}$ He explained that, for 37 years, the ANC "adhered strictly to a constitutional struggle. It put forward demands and resolutions; it sent delegations to the Government in the belief that African grievances could be settled through peaceful discussion and that Africans could advance gradually to full political rights. But white governments remained unmoved, and the rights of Africans became less instead of becoming greater". ${ }^{112}$ So the ANC contemplated the formation of armed resistance as a means of last resort because the government left them with no other choice. ${ }^{113}$

\section{Obstacles and constraints limiting the potential of the right to resist} Although legal norms enshrined in the ACDEG as well as other human and peoples' rights instruments are tools to empower citizens, the specific context of Africa is limiting the potential effects of empowerment. In most countries, the level of education is low; education in human rights is even lower. Hence, uneducated African citizens are not able to voice their concerns freely and vindicate respect for their rights. Given the democratic governance gap in most states, peoples rarely participate meaningfully in decision-making processes. When they are consulted, the terms of the discussions, along with the end results, are already pre-determined by elites (political and non-political), leaving little room for people's genuine participation. ${ }^{114}$ They are at the mercy of political and civil society elites who, most of the time, are self-proclaimed peoples' representatives. The former tend to manipulate the system in their favour or to interpret peoples' concerns and interests in a way that advances

110 N Mandela "I am prepared to die: Nelson Mandela's statement from the dock at the opening of the defence case in the Rivonia Trial" (Pretoria Supreme Court, 20 April 1964), available at: <http://db.nelsonmandela.org/speeches/pub_view.asp?pg=item\&ItemID= NMS010\&txtstr=rivonia\%20trial> (last accessed 11 December 2018).

111 Ibid.

112 Ibid.

113 Ibid.

114 See Ikome "Good coups and bad coups", above at note 99 at 20. 
their own political agendas. ${ }^{115}$ In this case, resistance led by civil society is illegitimate if the organizations are politically motivated and / or manipulated, not inclusive and not rights-oriented. Rather, such resistance under the disguise of popular uprisings should be considered an unconstitutional change of government or an attempt thereof.

Apart from the lack of agency necessary to ensure peoples' meaningful participation and to enable them to pursue their legal grievances, the democratic governance deficit that characterizes most African countries is another obstacle. Despite the duty to ensure the implementation of democratic values and principles, including ensuring democratic governance and public participation, ${ }^{116}$ some governments are not committed to real democracy and the rule of law. Leaders, whether elected or not, have often behaved undemocratically. Thus, they manipulate the laws as they wish, with a semblance of peoples' involvement. During the constitutional amendment processes that have taken place in some countries, leaders have ensured that peoples' involvement looks like peoples' engineered processes conducted in conformity with all legal requirements. In fact, the process is suggestive, and the people are not the ones who put forward certain constitutional values or principles but it is the leaders who initiate the process. In most cases, citizens are brought in simply to endorse processes engineered elsewhere and give them an air of democracy, rendering their participation merely cosmetic. ${ }^{117}$ This can be well exemplified in the cases of Rwanda, Burundi and Uganda. In these cases, the main objective of the constitutional amendment processes has been to ensure that the incumbent presidents continued in power, with the notable exception of Burundi President Nkurunziza who publicly and officially announced that he will step down in $2020 . .^{118}$

Finally, many states still resist the right to resist. Given the connotation of this right as a potential tool of insurrection, they do not want to have it in their constitutions or other domestic laws in order to avoid providing a

115 This was the situation in Burundi concerning the 2015 spring demonstrations against the president's third term. Decisions to hold those demonstrations were only taken by committees of opposition political parties and of mainstream civil society organizations, without consulting grassroots committees and their members.

116 ACDEG, arts 44(1), 2(10) and 3(7).

117 On the illegitimacy of constitutional processes in Africa, see Ikome "Good coups and bad coups", above at note 99 at 20. In the case of Rwanda, see for example T McVeigh "Rwanda votes to give President Paul Kagame right to rule until 2034" (20 December 2015) The Guardian, available at: <https://www.theguardian.com/world/2015/dec/20/ rwanda-vote-gives-president-paul-kagame-extended-powers> (last accessed 11 December 2018).

118 P Nkurunziza "Discours prononcé à l'occasion de la promulgation de la nouvelle Constitution de la République du Burundi" [Speech on the occasion of the promulgation of the new Constitution of the Republic of Burundi] (7 June 2018), paras 38-42 (copy on file with the author). 
legal basis for rebellious acts. ${ }^{119}$ However, reluctance of those states to enshrine the right to resist gross undemocratic practices into basic legal instruments is not well-founded. As mentioned above, resistance does not entail the right to use violence. In the first place, peaceful means of protest are the default resort for resistance. ${ }^{120}$ In fact, violence delegitimizes resistance in the absence of the use of violence by the state. Henceforth, the right to resist does not lay down the foundations for rebellions, coups d'état or other forms of insurrection, except in extreme situations when the state is too repressive and resorts to lethal attacks. Resistance should be conceptualized as a tool to ensure democracy and constitutional rule, and to prevent oppression and dictatorships on the continent.

\section{CONCLUSION}

The main spirit of the ACDEG is to ensure democratic governance founded on the rule of law and respect for human rights in Africa. ${ }^{121}$ While African states, individually or collectively, through regional or sub-regional organizations, continue to preach democracy, rule of law and respect for human rights, on the ground many states are actually standing in the way. In fact, leaders use the language of democracy and human rights for the sake of legitimizing their power and political interests, not as a vehicle for popular empowerment. ${ }^{122}$ Democracy is a people-centred and people-driven political system. It is characterized by peoples' right and ability to participate in the governance of one's state, ie the right to participate freely in domestic political processes and to have a government based on the relative free will of the people. The inalienable right to popular participation is violated by a strategy designed to deny rights, especially the related right of a people to political selfdetermination. ${ }^{123}$ In the eventuality of gross undemocratic practices as defined in this article, it is possible and legitimate for African citizens to resist violations of their democratic rights. The right to resist exists as a tool to protect other human rights. It is therefore an ultimum remedium [subsidiary right], ${ }^{124}$ the implementation of which presupposes exhaustion of constitutionally guaranteed avenues for the redress of human rights violations. Even if it has been a de facto right in the past, located somewhere between legality and illegality, it is a legal right today in accordance with some human rights

119 A few African countries have however constitutionalized the right to popular uprisings; see above at notes $60-65$.

120 Finlay Terrorism and the Right to Resist, above at note 8 at 92.

121 ACDEG, art 4(1).

122 Cheru "Democracy and people power", above at note 31 at 274.

123 JJ Paust "International law, dignity, democracy, and the Arab Spring" (2013) 46 Cornell International Law Journal 1 at 9.

124 R Fragkou "Le droit de résistance à l'oppression en droit constitutionnel comparé" [The right to resist oppression in comparative constitutional law] (2013) 65/4 Revue Internationale de Droit Comparé 831 at 849. 
instruments and national constitutions, though not explicitly provided for in the ACDEG. As has been highlighted in this article, the full enjoyment of rights is ultimately predicated on the struggle theory. The struggle theory provides a justification for the "African Spring". It is to be hoped that the ACDEG will contribute to give meaning to and reinforce Africans' right to resist gross undemocratic practices. This right is in fact an additional tool to ensure proper respect for and implementation of the ACDEG's ideals to take root on the African continent. 